\title{
PELAKSANAAN PELAYANAN PERIZINAN USAHA PERDAGANGAN SECARA ONLINE OLEH DINAS PENANAMAN MODAL DAN PELAYANAN TERPADU SATU PINTU DALAM UPAYA MENINGKATKAN INVESTASI DI KABUPATEN KUDUS
}

\author{
Sumarjono, Subarkah dan Suparnyo \\ Email : putrakalam@ymail.com, subarkah_sh@yahoo.com, suparnyo@umk.ac.id \\ Fakultas Hukum Universitas Muria Kudus
}

\begin{abstract}
ABSTRAK
Pelayanan publik dalam konsep good governance atau tata pemerintahan yang baik untuk meningkatkan kualitas layanan yang prima kepada masyarakat merupakan amanat dari Undang - Undang Nomor 25 Tahun 2009 tentang Pelayanan Publik, oleh sebab itu dalam rangka memberi kemudahan, kecepatan, dan ketepatan dalam penyelesaian permohonan SIUP di DPMPTSP Kabupaten Kudus maka dilaksanakanlah layanan SIUP secara online supaya masyarakat dapat melakukanya dari rumah atau kantor masing-masing tanpa harus datang ke Kantor DPMPTSP Kabupaten Kudus. Layanan SIUP online dilharapkan dapat memberikan kemudahan kepada masyarakat dibidang investasi penanaman modal yang manfaatnya dapat dirasakan dengan meningkatnya tingkat kesejahteraan oleh segenap masyarakat kabupaten Kudus sesuai visi yang diusung Kabupaten Kudus yaitu "Kudus Makin Sejahtera".
\end{abstract}

Kata Kunci : Layanan, Online, SIUP 


\section{PENDAHULUAN}

Pelayanan publik yang diselenggarakan oleh pemerintah pusat maupun pemerintah daerah diseluruh wilayah Negara Indonesia secara konstitusional telah diatur dalam Pasal 18A ayat (2) UUD NRI Tahun 1945 menyatakan bahwa :

"Hubungan keuangan, pelayanan umum, pemanfaatan sumber daya alam dan sumber daya lainnya antara pemerintah pusat dan pemerintah daerah diatur dan dilaksanakan secara adil dan selaras berdasarkan undang-undang”.

Ketentuan Pasal 18A ayat (2) tersebut kemudian dijabarkan dalam bentuk Undang-Undang Nomor 25 Tahun 2009 Tentang Pelayanan Publik, dengan demikian Undang-Undang Pelayanan Publik ini sudah seharusnya dalam tataran normatif harus menterjemahkan atau mengimplementasikan keinginan esensi Pasal 18A ayat (2) UUD NRI 1945. Dalam pengertian bahwa, ketentuan pasal ini harus memuat prinsip-prinsip dasar yang memungkinkan bagi terselenggaranya pelayanan masyarakat yang dapat dinikmati dan dirasakan manfaatnya oleh masyarakat.

Konsep Good governance atau tata pemerintahan yang baik merupakan salah satu upaya guna menciptakan keteraturan dan kesinambungan dalam sistem tata pemerintahan. Konsep ini, menjadi salah satu acuan dalam upaya peningkatan kualitas di beberapa aspek kepemerintahan. Suatu sistem tata kepemerintahan yang baik tidak hanya mengacu pada perbaikan yang nampak seperti sarana dan prasarana. Namun, pengelolaan sistem pemerintahan perlu diarahkan dari Bad governance menjadi Good governance. Seperti yang dikemukakan Dwiyanto, bahwa sistem pengelolaan pemerintahan di beberapa negara mengalami inefesiensi yang disebabkan oleh adanya praktik bad governance seperti tidak transparan, rendahnya partisipasi warga, rendahnya daya tanggap birokrasi, serta diskriminasi. Oleh karena itu, perlunya penataan sistem pemerintah melalui pelaksanaan konsep good governance. 30

Pelayanan publik pada dasarnya merupakan pemberian pelayanan kepada masyarakat terkait dengan pemenuhan kebutuhan masyarakat sebagai warga negara. Seperti yang dikemukakan Sampara dalam Sinambela pelayanan diartikan sebagai suatu kegiatan atau urutan kegiatan yang terjadi dalam interaksi langsung antar seseorang dengan orang lain atau mesin secara fisik, dan menyediakan kepuasan pelanggan. ${ }^{31}$ Penyelenggaraan pelayanan publik merupakan upaya negara untuk memenuhi kebutuhan dasar dan hak - hak sipil setiap warga negara atas barang, jasa, dan pelayanan administrasi yang disediakan oleh penyelenggara pelayanan publik. Bentuk kewajiban negara terhadap warga negaranya sesuai amanat Undang-Undang Dasar 1945 yakni untuk memenuhi kebutuhan dasar setiap warga negara salah satunya dengan melaksanakan pelayanan publik secara efektif dan efisien. ${ }^{32}$

Pada hakikatnya, pelayanan publik merupakan pemberian pelayanan prima kepada masyarakat yang merupakan perwujudan kewajiban aparatur pemerintah sebagai abdi masyarakat.

\footnotetext{
${ }^{30}$ Dwiyanto, Agus, "Mewujudkan Good Governance Melalui Pelayanan Publik", Gadjah Mada University Press, Yogyakarta, 2008, hlm. 18

${ }^{31}$ Sinambela, Lijan Poltak. Dkk. 2011 .Reformasi Pelayanan Publik, Jakarta: Bumi Aksara, 2011, hlm. 5

${ }^{32}$ Loc., Cit.
} 
Pemerintah sebagai lembaga penyedia pelayanan publik hendaknya mengoptimalkan penyelenggaraan pelayanan publik serta memperhatikan asas-asas dalam hal pelaksanaannya. Dalam Pasal 1 ayat (1) Undang-Undang Nomor 25 Tahun 2009 tentang Pelayanan Publik menyebutkan bahwa pelayanan publik merupakan kegiatan atau rangkaian kegiatan dalam rangka pemenuhan kebutuhan pelayanan sesuai dengan peraturan perundang - undangan bagi setiap warga negara dan penduduk atas barang, jasa, dan/atau pelayanan administratif yang disediakan oleh penyelenggara pelayanan publik. Dalam Undang-Undang Nomor 25 Tahun 2009 Pasal 1 ayat (2) disebutkan bahwa penyelenggara pelayanan publik yaitu penyelenggara adalah setiap institusi penyelenggara negara, korporasi, lembaga independen yang dibentuk berdasarkan undang -undang untuk kegiatan pelayanan publik, dan badan hukum lain yang dibentuk semata-mata untuk kegiatan pelayanan publik.

Ini berarti bahwa pemerintah dalam hal ini berupa badan, ataupun lembaga yang disebutkan di atas merupakan penyelenggara negara yang berhak memberikan pelayanan kepada setiap masyarakat atas kebutuhannya yang harus dijalankan sesuai dengan peraturan perundang - undangan yang ada. Bentuk kesesuaian antara pelayanan yang seharusnya terhadap pelayanan yang dilaksanakan dapat diukur melalui tingkat akuntabilitas pelayanan tersebut. Akuntabilitas merupakan salah satu bentuk tanggung jawab pemerintah terhadap masyarakat yang dapat dilihat melalui tingkat kesesuaian antara aktivitas birokrasi yang sesuai dengan nilai dan norma yang dianut masyarakat serta mampu mengakomodasi kebutuhan masyarakat yang sesungguhnya. ${ }^{33}$

Akuntabilitas merujuk pada bentuk pertanggungjawaban pemerintah atas tindakan yang dilakukan dalam masyarakat. JB Ghartey mengemukakan bahwa Akuntabilitas ditujukan untuk mencari jawaban atas pertanyaaan yang berhubungan dengan pelayanan apa, siapa, kepada siapa, milik siapa,yang mana dan bagaimana. Pertanyaan yang memerlukan jawaban tersebut antara lain apa yang harus dipertanggungjawabkan, mengapa pertanggungjawaban harus diserahkan, siapa yang bertanggung jawab terhadap berbagai kegiatan dalam masyarakat, apakah pertanggungjawaban berjalan seiring dengan kewenangan yang memadai dan lain sebagainya. ${ }^{34}$

Akuntabilitas dalam pelayanan publik, memberi jawaban atas pertanyaan tersebut yang merujuk kepada pertanggungjawaban pemerintah atas tindakan yang dilakukan baik dalam pengambilan keputusan dan maupun pelaksaan kebijakan-kebijakan dalam masyarakat, tanggungjawab pemerintah tersebut salah satunya dalam bentuk pelaksanaan pelayanan publik. Pelayanan publik yang akuntabel berarti suatu ukuran yang menunjukkan seberapa besar tingkat kesesuaian penyelenggaraan pelayanan dengan ukuran nilai-nilai atau norma eksternal yang ada di masyarakat atau yang dimiliki oleh para stakeholder.

Dengan demikian tolak ukur dalam akuntabilitas pelayanan publik adalah

\footnotetext{
${ }^{33}$ Kumorotomo, Wahyudi, "Akuntabilitas Birokrasi Publik :Sketsa pada Masa Transisi”, Pustaka Pelajar, Yogyakarta, 2013, hlm. 4

${ }^{34}$ Sedarmayanti, "Good Governance (Kepemerintahan yang Baik) Dalam Rangka Otonomi Daerah”, CV. Mandar Maju, Bandung , 2003, hlm. 70
} 
publik itu sendiri yaitu arti nilai-nilai atau norma-norma yang diakui, berlaku dan berkembang dalam kehidupan publik. nilai-nilai atau norma tersebut diantaranya transparansi pelayanan, pinsip keadilan, jaminan penegakan hukum, hak asasi manusia, orientasi pelayanan yang dikembangkan terhadap masyarakat pengguna jasa. ${ }^{35}$

Kabupaten Kudus merupakan salah satu kabupaten yang berada kawasan wilayah Propinsi Jawa Tengah yang menyajikan banyak peluang dan keuntungan dalam berinvestasi. Untuk melakukan investasi itulah, tentunya para investor perlu membuat surat ijin usaha perdagangan sebagai ijin turunannya dalam mendirikan sebuah usaha agar dapat menjalankan kegiatan usahanya. Surat ijin usaha perdagangan yang selanjutnya disebut SIUP adalah surat ijin yang wajib dimiliki seseorang atau suatu badan usaha untuk dapat melaksanakan kegiatan usaha perdagangan. Surat ijin usaha perdagangan merupakan surat ijin yang diberikan oleh menteri atau pejabat yang ditunjuk kepada pengusaha untuk melaksanakan kegiatan usaha dibidang perdagangan dan jasa. Surat Ijin Usaha Perdagangan (SIUP) diberikan kepada para pengusaha, baik perseorangan, firma, CV, PT, koperasi, maupun BUMN. Surat izin ini adalah surat yang diresmikan oleh instansi pemerintah bagi seseorang atau badan yang akan melaksanakan kegiatan bisnis atau usaha dalam bidang jasa atau perdagangan. Kepemilikan surat ijin usaha perdagangan merupakan kewajiban seseorang yang akan menjalankan suatu usaha perdagangan.

\footnotetext{
${ }^{35}$ Dwiyanto, dkk, "Reformasi Birokrasi Publik di Indonesia”, Yogyakarta, Pusat Studi kependudukan dan kebijakan UGM, 2012, hlm 57
}

Surat ini wajib dimiliki sebagai bukti pengesahan dari bisnis atau usaha yang dijalankan seperti yang tertuang dalam Peraturan Menteri Perdagangan Republik Indonesia No. 07/MDAG/PER/2/2017 tentang Perubahan Ketiga atas Permendag RI No. 36/MDAG/PER/9/2007 tentang Penerbitan Surat Ijin Usaha Perdagangan dalam Pasal 2 ayat (1) menyatakan: "setiap perusahaan perdagangan wajib memiliki SIUP”.

Oleh karena itu berdasarkan Peraturan Daerah Kabupaten Kudus Nomor 3 Tahun 2016 tentang Pembentukan dan Susunan Perangkat Daerah Kabupaten Kudus, Pemerintah Kabupaten Kudus kemudian membentuk suatu lembaga pelayanan perijinan yang bernama Dinas Penanaman Modal dan Pelayanan Terpadu Satu Pintu (DPMPTSP) diharapkan mampu memberikan pelayanan yang cepat, murah dan berorientasi pada kebutuhan dan kepuasan masyarakat guna meningkatkan investasi penanaman modal untuk terciptanya kesejahteraan masyarakat di Kabupaten Kudus dengan nama lembaganya yaitu Dinas Penanaman Modal dan Pelayanan Terpadu Satu Pintu (DPMPTSP) Kabupaten Kudus yang sebelumnya bernama BPMPPT (Badan Penanaman Modal dan Pelayanan Terpadu Satu Pintu). Pembentukan DPMPTSP sebenarnya merupakan bentuk langkah perbaikan sistem perijinan oleh pemerintah Kabupaten Kudus, yaitu dilaksanakannya sistem perijinan secara online khususnya dalam permohonan SIUP.

Dengan terbentuknya Dinas Penanaman Modal dan Pelayanan Terpadu Satu Pintu Kabupaten Kudus, ternyata belum bisa menghasilkan 
pelayanan yang maksimal. Terlihat dari beberapa informasi yang diterima bahwa pelayanan perijinan masih saja memunculkan masalah kesulitan dalam menjalankan sistem layanan tersebut. Sitem pelayanan permohonan SIUP online yang seharusnya bisa dilakukan oleh para pemohon dari rumah, di tempat kerja, dan di manapun tempat pemohon berada ternyata masih banyak para pemohon SIUP online yang melakukan permohonan SIUP secara online dengan cara mendatangi kantor DPMPTSP Kabupaten Kudus dengan meminta bantuan dari para pegawai yang melayani dan menjalankan sistem pelayanan permohonan SIUP secara online, sehingga pelaksanaannya menjadi kurang efektif. Hal tersebut tentu menjadi suatu permasalahan dari tujuan dilaksanakannya sistem layanan SIUP online yang seharusnya pemohon bisa melakukan permohonan SIUP secara online di manapun berada dan di waktu kapan pun ternyata masih banyak yang harus datang ke kantor sesuai dengan jam kerja kantor. Dari latar belakang masalah tersebut, masalah yang akan dibahas antara lain :

1. Bagaimana pelaksanaan pelayanan perijinan usaha perdagangan secara online pada Dinas Penanaman Modal \& Pelayanan Terpadu Satu Pintu?

2. Bagaimana dampak pelayanan perijinan usaha perdagangan secara online terhadap nilai investasi penanaman modal usaha untuk kesejahteraan masyarakat di Kabupaten Kudus?

\section{METODE PENELITIAN}

Penelitian ini merupakan jenis penelitian empiris yang bersifat deskriptif. Menurut Ronny Hanitijo Soemitro pendekatan yuridis empiris atau sosiologis adalah penelitian yang didasarkan pada langkah-langkah observasi dan analisis yang bersifat empiris-kuantitatif. $^{36}$ Data yang diperoleh, dianalisis secara metode kualitatif berdasarkan data kuantitatif yaitu memaparkan atas hasil penelitian berupa data yang diperoleh di lapangan sebagai bahan pembahasan dari hasil penelitian. Dari analisis data tersebut, dilanjutkan dengan menarik kesimpulan metode induktif yaitu suatu cara berfikir secara khusus lalu kemudian diambil kesimpulan secara umum guna menjawab permasalahan yang diajukan.

\section{HASIL PENELITIAN DAN PEMBAHASAN}

1. Pelaksanaan

Layanan

Permohonan Surat Ijin Usaha

Perdagangan Secara Online Di DPMPTSP Kabupaten Kudus

Pelakasanaan layanan SIUP online pertama kali pada awal Bulan januai 2016 dilaksanakan dengan menggunakan sistem SIPTO berdasarkan Perbup Kudus Nomor 24 Tahun 2015 tentang Pendelegasian dan Pelimpahan Kewenangan Penandatanganan Perijinan dan Non Perijinan Kepada Kepala Badan Penanaman Modal dan Pelayanan Perijinan Terpadu Kabupaten Kudus, kemudian mulai pada tanggal 6 Juli 2018 pelaksanaan layanan SIUP online dirubah dengan menggunakan sistem OSS berdasarkan Peraturan Pemerintah Nomor 24 Tahun 2018 tentang Pelayanan Perijinan Berusaha Terintegrasi Secara Elektronik.

SIPTO yang dijalankan oleh DPMPTSP dalam layanan SIUP online merupakan sistem yang dibuat dan dikembangkan sendiri oleh DPMPTSP

\footnotetext{
36 Rony Harnitijo S, "Metodologi Penelitian Hukum dan Jurimetri", Ghalia Indonesia, Jakarta, 1990, hlm. 35
} 
berdasarkan pendelegasian dari Bupati Kudus yang berakibat pada pelimpahan tanggung jawab sepenuhnya pada DPMPTSP dalam menjalankan sistem layanan SIUP online dengan cara SIPTO tersebut. SIPTO dibuat dan dikembangkan oleh DPMPTSP Kabupaten Kudus sebagai bentuk kewenangan bebas (freies ermessen) kepada pejabat terkait karena belum ada peraturan perundangan yang mengatur tentang mekamisme dan tata cara dalam melayani sistem layanan perijinan secara online, sehingga freies ermessen diartikan sebagai salah satu sarana yang memberikan ruang bergerak bagi pejabat atau badan-badan administrasi negara untuk melakukan tindakan tanpa harus terikat sepenuhnya pada Undangundang. ${ }^{37}$

Sedangkan pelaksanaan layanan SIUP online dengan sistem OSS dilaksanakan untuk mengganti SIPTO karena terbitnya PP No. 24 Tahun 2018 tentang Pelayanan Perijinan Berusaha Terintegrasi Secara Elektronik yang dikeluarkan oleh pemerintah pusat. Sebagai bagian dari sistem pemerintahan yang berlaku dalam konsep Negara Kesatuan Republik Indonesia maka DPMPTSP sebagai bagian dari Pemerintah Daerah di Kabupaten Kudus harus tunduk terhadap pemerintah pusat, sehingga tanggungjawab pelaksanaan tugas-tugas pemerintahan pada dasarnya tetap berada di tangan pemerintah pusat. Akan tetapi, sistem pemerintahan Indonesia yang salah satunya menganut asas negara kesatuan yang

\footnotetext{
37 Marcus Lukman, “Eksistensi Peraturan Kebijaksanaan dalam Bidang Perencanan dan Pelaksanaan di Daerah serta Dampaknya terhadap Pembangunan Materi Hukum Tertulis Nasional", Disertasi Universitas Padjadjaran, Bandung, 1996, hlm. 205
}

didesentralisasikan, menyebabkan ada tugas-tugas tertentu yang di urus sendiri, sehingga menimbulkan hubungan timbal balik yang melahirkan adanya hubungan kewenangan dan pengawasan khususnya dalam layanan SIUP dengan sistem OSS. ${ }^{38}$

Setelah dilaksanakannya layanan SIUP online dengan menggunakan sistem OSS sesuai dengan Peraturan Pemerintah Nomor 24 Tahun 2018 tentang Percepatan Perijinan Berusaha Terintregasi Elektronik yang dimulai pada tanggal 6 Juli 2018 di DPMPTSP Kabupaten Kudus terjadi perubahan sistem dalam mekanisme permohonan SIUP secara online. Jika dalam penggunaan cara SIPTO merupakan sistem yang diciptakan dan dikembangkan sendiri oleh DPMPTSP Kabupaten Kudus, sedangkan sistem OSS mekanisme dan tata caranya dibuat oleh Kementerian Kordinasi Bidang Perekonomian, di samping para pemohon sendiri banyak yang tidak mampu mengakses internet untuk mengajukan permohonan SIUP secara online, ternyata sistem OSS yang baru dijalankan juga membuat beberapa pegawai yang melayani di DPMPTSP Kabupaten Kudus belum dapat menguasai sepenuhnya atas sistem tersebut.

Implementasi pelayanan perizinan berbasis teknologi informasi di DPMPTSP Kabupaten Kudus belum baik. Pada transparansi, teknologi informasi belum dapat membantu masyarakat. Keterbukaan informasi belum diakses secara maksimal karena sistem layanan permohonan SIUP secara online tidak dimanfaatkan.

\footnotetext{
38 Ni'matul Huda, “Hukum Tata Negara Indonesia”, Grafindo Persada, Jakarta 2005, hlm. 93.
} 
Kurangnya peran masyarakat membuat partisipasi yang diharapkan belum terjadi. Namun penggunaan teknologi dalam penyampaian pengaduan dan saran sudah meningkat. Efisiensi yang terjadi hanya membantu pegawai dalam meningkatkan kecepatan pelayanan. Sistem layanan SIUP secara online belum efisien karena banyaknya pelayanan permohonan SIUP masih banyak dilakukan di Kantor DPMPTSP Kabupaten Kudus. Komunikasi antar pegawai serta antar pegawai dan masyarakat terjalin dengan baik. Penyampaian informasi di DPMPTSP Kudus terlaksana dengan bagus. Namun sosialisasi sistem online kurang baik. Sumber daya anggaran, peralatan, serta informasi dan kewenangan sudah memadai. Sementara sumber daya manusia masih perlu ditingkatkan. Disposisi pegawai terlihat baik. Pegawai memperlihatkan kinerja yang bagus, ramah, dan bersungguh-sungguh dalam menjalankan tugasnya. Struktur birokrasi terpangkas dengan efisien. Namun penerapan sistem layanan SIUP online di DPMPTSP Kabupaten Kudus belum efisien karena pemanfaatannya yang kurang oleh masyarakat.

\section{Dampak Layanan SIUP Online di DPMPTSP Kabupaten Kudus Terhadap Peningkatan Investasi Penanaman Modal}

Dalam rangka mendorong
pertumbuhan $\begin{array}{r}\text { ekonomi } \\ \text { melalui }\end{array}$
peningkatan investasi penanaman modal
usaha, Pemerintah Kabupaten Kudus
memberikan perhatian yang lebih besar
pada peran usaha mikro, kecil, dan
menengah. Dimana dalam
pelaksanaanya pelaku dunia usaha
sangat membutuhkan informasi
investasi dan perizinan.

Adapun tujuan dilaksanakannya penyelenggaraan layanan SIUP secara online di Kantor DPMPTSP Kabupaten Kudus menurut Ibu Maya Tyas Kaesti S.SI adalah: ${ }^{39}$

1. Meningkatkan kualitas pelayanan publik yang prima kepada masyarakat dengan memberikan kemudahan perizinan, biaya yang transparan, dan ketepatan dalam penyelesaian;

2. Meningkatkan pengembangan invesatsi penanaman modal di Kabupaten Kudus

3. Memberikan kontribusi Pendapatan Asli Daerah kepada Pemerintah daerah Kabupaten Kudus akses.

Sedangkan sasaran penyelenggaraan layanan SIUP secara online di DPMPTSP Kabupaten Kudus, adalah: ${ }^{40}$

1. Terwujudnya pelayanan publik yang cepat, murah, mudah, transparan, pasti, dan terjangkau;

2. Meningkatkan hak-hak masyarakat terhadap pelayanan publik untuk memperoleh pelayanan yang efektif, efisien, dan terpadu.

Berikut merupakan hasil temuan dari penulis atas data penerbitan SIUP beserta nilai investasi dari Tahun 2014 2017, dimana pada Tahun 2014-2015 belum dilaksanakan layanan SIUP online kemudian Tahun 2016-2017 sudah dilaksanakan layanan SIUP secara online. Data tersebut oleh penulis digunakan sebagai perbandingan guna mengukur keberhasilan layanan SIUP

\footnotetext{
39 Maya Tyas Kaesti "wawancara pribadi", Kepala Bidang Perencanaan Perijinan pada Dinas Penanaman Modal dan Pelayananan Terpadu Satu Pintu, 22 Januari 2018, Kantor DPMPTSP, Kudus.

40 Maya Tyas Kaesti "wawancara pribadi", Kepala Bidang Perencanaan Perijinan pada Dinas Penanaman Modal dan Pelayananan Terpadu Satu Pintu, 4 Februari 2018, Kantor DPMPTSP, Kudus.
} 
secara online terhadap peningkatan nilai investasi yang ada di DPMPTSP Kabupaten Kudus.

Tahun 2014 terbit 1.201 SIUP dengan target Rp. 8.262.742.550.415,00 dan realisasi Rp. 8.826.195.298.062,00; Tahun 2015 terbut 1.011 SIUP dengan target Rp. 9.089.016.805.457,00 dan realisasi Rp. 17.620.465.287.032,00; Tahun 2016 terbit 672 SIUP dengan target Rp. 9.997.918.486.002,00 dan realisasi Rp. 18.613.008.500.649,00; Tahun 2017 terbit 335 SIUP dengan target Rp. 10.997.710.334.603,00 dan realisasi Rp. 11.463.103.884.050,00. Sumber data dari hasil penelitian di Kantor DPMPTSP Kabupaten Kudus

Jika dilihat dari data tersebut di atas bisa dilihat bahwa jumlah penerbitan SIUP sejak dilaksanakannya layanan SIUP secara online, yaitu pada Tahun 2016 dan 2017 mengalami penurunan jika dibandingkan dengan jumlah SIUP yang diterbitkan pada Tahun 2014 dan 2015 sebelum dilaksanakannya layanan SIUP online di DPMPTSP Kabupaten Kudus. Tetapi jumlah nilai investasi sejak dilaksanakannya layanan SIUP secara online realisasinya selalu mengalami peningkatan dari jumlah target yang direncanakan.

Berdasarkan temuan yang didapat oleh penulis dari hasil penelitian di DPMPTSP mengenai strategi layanan SIUP online untuk meningkatkan investasi penanaman modal dengan data penerbitan SIUP berikut nilai investasinya setelah dilaksanakannya layanan SIUP online di DPMPTSP Kabupaten Kudus bertujuan agar layanan SIUP secara online dapat memberikan pelayanan kepada masyarakat dengan kemudahan, kecepatan dan ketepatan dalam penyelesaian permohonan SIUP agar investasi penanaman modal di
Kabupaten Kudus semakain bertambah pesat dan dapat meningkatkan kesejahteraan pada warga masyarakat di Kabupaten Kudus.

Akan tetapi jika dilihat dari data penerbitan SIUP yang dikeluarkan setelah dilaksanakanya layanan SIUP secara online ustru menunjukkan penurunan terhadap penerbitan jumlah SIUP yang dikeluarkan sebelum adanya layanan SIUP online atau pada saat masih digunakan cara manual. Hal tersebut menurut pejabat di DPMPTSP karena sudah banyak SIUP yang sudah dikeluarkan pada tahun tahun sebelumnya, sehingga hal itu berpengaruh terhadap rencana tata ruang wilayah Kabupaten Kudus sebagai dasar untuk mengeluarkan ijinijin usaha baru yang disesuaikan dengan Perda Kabupaten Kudus Nomor 16 Tahun 2012 tentang Rencana Tata Ruang Wilayah Kabupaten Kudus Tahun 2012 - 2032.

Sedangkan jika dilihat dari data jumlah nilai investasi penanaman modal setelah dilaksanakannya layanan SIUP secara online antara Tahun 2016-2017 dalam realisasinya selalu mengalami peningkatan dalam jumlah yang cukup besar, hal itu berbanding terbalik dengan jumlah SIUP yang dikeluarkan. Tetapi oleh pejabat yang berwenang mengatakan bahwa pertambahan nilai investasi penanaman modal tersebut terjadi karena perkembangan dan pertumbuhan perusahaan perusahaan yang pernah mengajukan SIUP berkembang menjadi perusahaan perusahaan besar dengan aset berupa mesin mesin modern yang mendukung dalam peningkatan kapasitas produksi.

Oleh karena itu dari hasil penelitian yang dilakukan penulis berkesimpulan bahwa layanan SIUP online belum membawa suatu keberhasilan dalam 
pelaksanaanya. Di samping pemohon SIUP banyak yang masih datang ke Kantor DPMPTSP untuk mengakses pengajuannya baik karena pemohon tidak bisa ataupun pemohon merasa kurang percaya diri untuk mengakses internet secara mandiri, jumlah SIUP yang diterbitkan sangat sedikit jika dibanding pada saat belum dilaksanakannya layanan SIUP secara online. Jumlah nilai investasi penanaman modal setelah adanya layanan SIUP online tidak disebabkan karena semakin banyaknya jumlah SIUP yang diterbitkan, tetapi karena perkembangan usaha dari perusahaan perusahaan yang pernah mengajukan izin SIUP.

\section{Kesimpulan}

a. Berdasarkan pembahasan di atas pelaksanaan layanan SIUP online di DPMPTSP Kabupaten Kudus dilaksanakan menggunakan cara SIPTO (Sistem Informasi Pelayanan Terpadu Online) dan sistem OSS (Online Single Submission). SIPTO dibuat dan laksanakan oleh DPMPTSP berdasarkan pada Perbup Kudus Nomor 24 Tahun 2015 Kudus Nomor 24 Tahun 2015 tentang Pendelegasian dan Pelimpahan Kewenangan Penandatanganan Perijinan dan Non Perijinan Kepada Kepala Badan Penanaman Modal dan Pelayanan Perijinan Terpadu Kabupaten Kudus, sedangkan OSS dilaksanakan setelah keluarnya Peraturan Pemerintah Nomor 24 Tahun 2018 tentang Pelayanan Perijinan Berusaha Terintegrasi Secara Elektronik dengan petunjuk dan tata cara permohonannya sesuai dengan Pedoman Perijinan Berusaha Melalui OSS yang dikeluarkan oleh Kementerian Koordinator Bidang Perekonomian. Implementasi layanan SIUP berbasis teknologi informasi di DPMPTSP Kabupaten Kudus belum baik. Kurangnya peran masyarakat membuat partisipasi yang diharapkan belum terjadi. Sistem layanan SIUP secara online belum efisien karena banyaknya pemohon penerbitan SIUP masih banyak dilakukan di Kantor DPMPTSP Kabupaten Kudus, karena kurangnya sosialisasi layanan sistem online yang telah dijalankan oleh DPMPTSP belum banyak diketahui oleh masyarakat.

b. Layanan SIUP online yang dilaksanakan oleh DPMPTSP Kabupaten Kudus belum membawa suatu keberhasilan dalam meningkatkan nilai investasi penanaman modal secara maksimal. Peningkatan nilai investasi penanaman modal di Kabupaten Kudus yang terjadi setelah dilaksanakannya layanan SIUP online bukan karena meningkatnya jumlah SIUP yang diterbitkan, tetapi disebabkan karena perusahaan-perusahaan yang telah memiliki ijin SIUP mengalami perkembangan dalam bidang usahanya dengan memanfaatkan kemajuan tehnologi yang ada para pelaku usaha menambah mesin-mesin yang lebih baik sehingga bisa menambah kapasitas produksi yang dihasilkannya.

\section{Saran}

a. Untuk mencapai suatu tujuan dilaksanakannya layanan SIUP secara online untuk memberikan kemudahan, kecepatan, dan ketepatan penyelesaian dalam permohonan SIUP, sebaiknya DPMPTSP lebih sering melakukan sosialisasi kepada masyarakat baik secara langsung maupun dengan membuat pamflet tentang tata cara dan mekanismenya dalam mengakses layanan SIUP atau perijinan lainnya yang berbasis tehnologi elektronik atau secara online, sehingga masyarakat 
berani mencoba atau mau belajar secara mandiri untuk melakukan permohonan SIUP atau perijinan lainnya secara online.

b. Hendaknya Pemerintah Kabupaten Kudus mempermudah ijin ijin prinsip dalam segala bidang usaha yang dapat menarik investor guna menanamkan modalnya di Kabupaten Kudus dengan meninjau kembali tentang Rencana Tata Ruang Wilayah di Kabupaten Kudus, sehingga dengan banyaknya nilai investasi penanaman modal yang ada bisa dirasakan manfaatnya dalam membantu penyediaan lapangan kerja dan dapat meningkatkan kesejahteraan masyarakat di Kabupaten Kudus.

\section{DAFTAR PUSTAKA}

Dwiyanto, dkk, 2012, "Reformasi Birokrasi publik di Indonesia", Pusat Studi Kependudukan dan kebijakan UGM, Yogyakarta.

Lijian Poltak Sinambela, 2006,

"Reformasi Pelayanan Publik,

Teori, Kebijakan dan

Implementasi," Bumi Aksara,

Bandung.

Ni'matul Huda, 2005, “Hukum Tata

Negara Indonesia", Grafindo

Persada, Jakarta.

Raba Manggaukang, 2006,

"Akuntabilitas, Konsep dan

Implementa”, Universitas

Muhammadiyah Malang Press, Malang.

Ridwan H.R., 2011, "Hukum

Administrasi Negara", Edisi Revisi,
Cetakan ke-6, Rajawali Pers, Jakarta

Rony Harnitijo S,1990, "Metodologi Penelitian Hukum dan Jurimetri", Ghalia Indonesia, Jakarta.

Sedarmayanti, 2003, “Good Governance (Kepemerintahan yang Baik) Dalam Rangka Otonomi Daerah”, CV. Mandar Maju, Bandung.

, 2014, “Manajemen Sumber Daya

Manusia Reformasi Birokrasi dan Manajemen Pegawai Negeri Sipil", Refika Aditama, Bandung.

Soerjono Soekanto, 1985, "Pengantar

Penelitian Hukum", Balai Pustaka, Jakarta.

Y. Slamet, 1994, "Pembangunan Masyarakat Berwawasan Partisipasi”, Sebelas Maret University Press, Surakarta.

\section{Undang-Undang}

Peraturan Perundang-Undangan dan Peraturan Kebijaksanaan

Undang-Undang Dasar Negara Republik Indonesia Tahun 1945 Undang -Undang Nomor 30 Tahun 2014 tentang Administrasi Negara Peraturan Pemerintah Nomor 24 Tahun 2018 tentang Pelayanan Perijinan Berusaha Terintegrasi Secara Elektronik.

Permendag Nomor 14/MDAG/PER/3/2016 tentang 
Perubahan Atas Permendag Nomor

77/M-DAG/PER/12/2013 tentang

Penerbitan

Surat Ijin Usaha Perdagangan dan

Tanda Daftar Perusahaan Secara

Simultan Bagi Perusahaan

Perdagangan.

Permendag No. 07/M-

DAG/PER/2/2017 tentang

Perubahan Ketiga atas atas

Permendag No. 36/M-

DAG/PER/9/2007 tentang

Penerbitan Surat Usaha Ijin

Perdagangan.

Peraturan Bupati Kudus Nomor 24

Tahun 2015 tentang Pendelegasian

dan Pelimpahan Kewenangan
Penandatanganan Perijinan dan

Non Perijinan Kepada Kepala

Badan Penanaman Modal dan

Pelayanan Perijinan Terpadu

Kabupaten Kudus

\section{Jurnal/Karya Ilmiah}

Marcus Lukman, 1996, "Eksistensi Peraturan Kebijaksanaan dalam Bidang Perencanan dan Pelaksanaan di Daerah serta Dampaknya terhadap Pembangunan Materi Hukum Tertulis Nasional", Disertasi Universitas Padjadjaran, Bandung. 